\title{
EVALUASI PERLAKUAN AKUNTANSI ATAS PIUTANG TAK TERTAGIH PADA PT. ANGKASA PURA I (PERSERO) CABANG MANADO
}

\author{
Ribka Josevira Logor $^{1}$, Harijanto Sabijono ${ }^{2}$, Stanly W. Alexander ${ }^{2}$ \\ ${ }^{1,2}$ Jurusan Akuntansi, Fakultas Ekonomi dan Bisnis, Universitas Sam Ratulangi, J1. Kampus Bahu, Manado, \\ 95115, Indonesia \\ ${ }^{1}$ Email: ribkajosevira13@gmail.com
}

\begin{abstract}
The Bad Debts is very influential on the decline in operating profit of the companyThis study aims to determine the presentation, recognition and measurement and disclosure of uncollectible receivables at PT. Angkasa Pura I (Persero) Manado Branch and conformity with PSAK 50, 55 and 60. This study uses qualitative research methods with descriptive methods. The evaluation method used is collecting data obtained through interviews and documentation, then analyzing the data and finally data processing data. The results of this study are receivables which are categorized into uncollectible receivables, namely receivables that have more than 6 months of maturity. The treatment of uncollectible receivables from PT. Angkasa Pura I (Persero) complies with Financial Accounting Standards namely PSAK 50, 55, and 60. The accounting treatment of uncollectible receivables must also be given special attention by companies to minimize uncollectible receivables.
\end{abstract}

Keywords: accounting treatment; bad debts; PSAK 50; PSAK 55; PSAK 60

\section{PENDAHULUAN}

Piutang tidak tertagih berpengaruh terhadap efektivitas dari kas perusahaan karena merupakan kerugian dari pendapatan perusahaan dan harus dicatat dalam ayat jurnal yang tepat dan ditangani dengan metode yang tepat. Kerugian pendapatan atau penurunan laba akibat dari piutang tak tertagih diakui sebagai beban piutang tak tertagih atau beban piutang ragu-ragu. Risiko piutang tidak tertagih seharusnya bisa diantisipasi oleh perusahaan namun perusahaan tidak bisa memprediksi klien yang memiliki piutang tak tertagih yang tidak bisa membayar kewajibannya terhadap perusahaan.

PT. Angkasa Pura I merupakan Badan Usaha Milik Negara (BUMN) yang ada dalam lingkungan Departemen Perhubungan yang selalu memberikan kontribusi maksimal kepada negara melalui usaha dan pelayanan dan jasa kebandarudaraan. PT.Angkasa Pura I memiliki 3 tugas utama yaitu: menyelenggarakan keselamatan penerbangan, keamanan penerbangan, kenyamanan dan kemudahan. Ketiga hal ini merupakan titik sentral perhatian PT. Angkasa Pura I (Persero). Piutang tak tertagih sangat berpengaruh terhadap laba operasional dimana laba operasional perusahaan menurun. Adapun faktor-faktor yang menyebabkan piutang tak tertagih ada 2 faktor yaitu : faktor internal dan faktor eksternal. Faktor internal dapat berasal dari pihak yang memberikan piutang (kreditur) dan faktor eksternal berasal dari pihak yang memiliki hutang (debitur). Piutang pada PT. Angkasa Pura I sendiri terdiri atas 2 bagian besar yaitu: aeronautika dan non aeronautika. Adapun aeronautika yaitu yang berhubungan dengan perusahaan angkutan udara sedangkan untuk non aeronautika merupakan pihak perusahaan yang melakukan kegiatan usaha non angkutan udara (non airlines).

\section{TINJAUAN PUSTAKA}

Konsep akuntansi. Kartikahadi et al. (2016:3) menyatakan bahwa akuntansi ialah suatu sistem informasi keuangan, yang bertujuan untuk menghasilkan dan melaporkan 
informasi yang relevan bagi berbagai pihak yang berkepentingan. Menurut Lubis (2011:2), akuntansi adalah sistem informasi yang menyediakan laporan bagi para pihak pengambil keputusan (stakeholder) mengenai aktivitas ekonomi dan kondisi perusahaan. Menurut Suwardjono (2015:10) akuntansi dapat didefinisikan sebagai seperangkat yang mempelajari perekayasaan penyediaan jasa berupa informasi keuangan kuantitatif unit-unit organisasi dalam suatu lingkungan Negara tertentu dan cara penyampaian (pelaporan) informasi tersebut kepada pihak yang berkepentingan untuk dijadikan dasar pengambilan keputusan ekonomik.

Perlakuan akuntansi. Pura (2012:25) menyatakan bahwa ada beberapa konsep yang terkait dengan perlakuan akuntansi yaitu konsep pengakuan, konsep pengukuran/penilaian, konsep pencatatan, konsep penyajian, dan konsep pengungkapan. Konsep-konsep perlakuan akuntansi tersebut dapat diuraikan sebagai berikut: (1) pengakuan dalam akuntansi adalah sebuah proses penetapan terpenuhi criteria pencatatan suatu kejadian atau peristiwa dalam catatan akuntansi, sehingga kejadian atau peristiwa itu akan menjadi bagian yang melengkapi unsur aset, kewajiban, ekuitas, pendapatan, dan beban sebagaimana akan termuat pada laporan keuangan dari entitas pelaporan yang bersangkutan; (2) pengukuran dalam akuntansi adalah sebuah proses penempatan nilai uang demi mengakui dan memasukkan setiap pos pada laporan keuangan; (3) pencatatan dalam akuntansi adalah sebuah proses analisis atau suatu transaksi atau peristiwa keuangan yang terjadi dalam entitas dengan cara menempatkan transaksi di sisi debet dan sisi kredit; (4) penyajian dalam akuntansi adalah sebuah proses penempatan suatu akun secara terstruktur pada laporan keuangan; dan (5) pengungkapan dalam akuntansi adalah sebuah proses penjelasan secara naratif atau rincian menyangkut angka-angka yang tertera dalam laporan neraca, laporan laba rugi, dan laporan arus kas.

Pengertian piutang. Kasmir (2015:115) menyatakan piutang menunjukkan adanya klaim perusahaan kepada pihak perusahaan lain akibat kejadian di waktu sebelumnya dalam bentuk uang, barang, jasa atau dalam bentuk aktiva non kas lainnya yang harus dilakukan penagih (collect) pada tanggal jatuh temponya. Hery (2015:29) mendefinisikan istilah piutang adalah mengacu pada sejumlah tagihan yang akan diterima oleh perusahaan (umumnya dalam bentuk kas) dari pihak lain, baik sebagai akibat penyerahan barang dan jasa secara kredit piutang diklasifikasikan sebagai lancar (jangka pendek) atau tidak lancar (jangka panjang). Menurut PSAK No.1 revisi 2013 (IAI, 2013:PSAK No.1) piutang merupakan aset lancar yang dijual, dikonsumsi dan direalisasikan sebagai bagian siklus operasi normal meskipun aset tersebut tidak diperkirakan untuk direalisasikan dalam jangka waktu dua belas bulan setelah periode pelaporan.

Ciri-ciri piutang yaitu adanya nilai jatuh tempo, adanya tanggal jatuh tempo, dan adanya bunga yang berlaku.

Klasifikasi piutang. Menurut Martani et al. (2015:196-197) piutang dapat diklasifikasikan menjadi tiga yaitu:

1. Piutang dagang. Piutang dagang merupakan klaim suatu perusahaan pada pihak lain baik yang terkait dengan transaksi penjualan/pendapatan.

2. Wesel tagih. Wesel tagih merupakan klaim perusahaan kepada pihak ketiga yang didukung janji tertulis untuk membayar dalam jangka waktu tertentu.

3. Piutang penghasilan. Penggunaan dasar waktu dalam akuntansi mengakibatan adanya pengakuan terhadap penghasilan-penghasilan yang masih akan diterima. Penghasilanpenghasilan seperti itu atas dasar waktu sehingga pada akhir periode dihitung berapa jumlah yang sudah menjadi pendapatan dan jumlah tersebut dicatat sebagai piutang penghasilan.

Pengertian piutang tak tertagih. Kieso et al. (2008:350) menyatakan bahwa piutang usaha tak tertagih adalah kerugian pendapatan yang memerlukan, melalui ayat jurnal pencatatan yang tepat dalam akun, penurunan aktiva piutang usaha serta penurunan yang berkaitan dengan laba dan ekuitas pemegang saham. Menurut Ahmad (2015:67) dalam buku 
teori akuntansi, menyatakan bahwa piutang usaha tak tertagih adalah kerugian pendapatan yang memerlukan, melalui ayat jurnal pencatatan yang tepat dalam akun, penurunan aktiva piutang usaha serta penurunan yang berkaitan dengan laba dan ekuitas pemegang saham.

Jenis piutang tidak tertagih diantaranya: kredit dalam perhatian khusus, kredit kurang lancar, kredit diragukan, kredit macet.

Konsep perlakuan akuntansi untuk piutang tak tertagih. Terdapat dua metode akuntansi untuk piutang tak tertagih:

1. Metode Penghapusan Langsung (direct write-off method). Mencatat beban piutang tak tertagih hanya pada saat suatu piutang dianggap benar-benar tak tertagih. Piutang tersebut kemudian dihapus dan dibebankan pada perkiraan kerugian piutang.

2. Metode Penyisihan (allowance method). Mencatat beban piutang tak tertagih dengan mengestimasi jumlah piutang tak tertagih pada akhir periode akuntansi. Dalam pencatatannya, beban kerugian piutang di bagian debet dan cadangan kerugian piutang di bagian kredit.

Menurut PSAK 50 instrumen keuangan: penyajian dimaksudkan untuk menetapkan prinsip-prinsip untuk menentukan apakah instrumen keuangan merupakan liabilitas atau ekuitas serta menetapkan prinsip-prinsip untuk menyaling hapuskan aset keuangan dengan liabilitas keuangan (IAI, 2014:PSAK 50). Hal ini piutang tak tertagih menjadi kerugian bagi perusahaan yang menyebabkan saldo perusahaan menjadi menurun. Penyajian piutang tak tertagih pada laporan keuangan tidak disajikan secara langsung tetapi menurut nilai sekarang yang telah mengalami penurunan nilai. Menurut PSAK No. 55 (IAI, 2014:PSAK 55) : pengakuan dan pengukuran yaitu piutang setiap pelaporan harus dievaluasi apakah terdapat bukti objektif aset keuangan tersebut mengalami penurunan nilai. Bukti objektif yaitu kerugian diukur berdasarkan selisih antara nilai tercatat piutang dengan nilai kini estimasi arus kas masa depan yang terjadi akibat dari satu atau lebih peristiwa setelah pengakuan awal yang merugikan dan berdampak pada arus kas di masa depan contohnya kerugian atas piutang tak tertagih. Menurut PSAK 60 instrumen keuangan : pengungkapan (IAI, 2014:PSAK 60) mengharuskan entitas mengungkapkan informasi dalam laporan keuangan yang dengan informasi dimaksud pengguna menjadi mampu mengevaluasi signifikansi instrumen keuangan terhadap posisi keuangan dan kinerja keuangan entitas dan risiko-risiko apa saja yang ditimbulkan oleh instrumen keuangan dan sejauh mana risiko-risiko itu berdampak terhadap entitas selama periode dan pada akhir periode yang dilaporkan, serta bagaimana entitas mengelola risiko-risiko tersebut.

\section{METODE PENELITIAN}

Jenis penelitian ini merupakan penelitian kualitatif dengan menggunakan pendekatan deskriptif. Sugiyono (2015:36) menyatakan penelitian deskriptif adalah penelitian yang dimaksudkan menyelidiki keadaan, kondisi atau hal-hal lain yang sudah disebutkan yang hasilnya dipaparkan dalam bentuk laporan penelitian. Penelitian ini dilakukan di PT. Angkasa Pura I (Persero) Bandara Sam Ratulangi Manado yang beralamat di Jl. A.A Maramis, Kota Manado. Penelitian ini dilakukan bulan Januari 2020 sampai dengan selesai.

Data yang digunakan dalam penelitian ini yaitu data kualitatif dan kuantitatif. (1) Data kuantitatif berupa data yang dapat diukur dalam skala numerik dan dalam penelitian ini data kuantitatif yang digunakan yaitu daftar piutang tak tertagih yang ada diperusahaan. (2) Data kualitatif adalah data yang tidak dapat diukur dalam skala numeric yaitu berupa deskripsi prosedur secara naratif atau kata-kata dan data kualitatif yang digunakan dalam penelitian ini berupa data mengenai kondisi perusahaan, sejarah perusahaan, profil perusahaan, struktur organisasi perusahaan, hasil wawancara dengan pihak perusahaan.

Menurut Sujarweni (2014:73), sumber data merupakan subjek dari mana awal data penelitian itu diperoleh. Adapun data yang diperlukan dalam penelitian ini adalah data primer 
dan data sekunder yang digunakan dalam penelitian ini adalah data primer. Data primer adalah data yang diperoleh langsung dari subjek penelitian. Metode pengumpulan data pada penelitian ini yaitu wawancara secara langsung dengan pihak perusahaan yaitu manajer bagian account receivable dan staf bagian account receivable dan staf bagian accounting, dan dokumentasi berupa daftar piutang tak tertagih perusahaan. Teknik pengumpulan data pada penelitian ini yaitu: (1) melakukan pengumpulan data yang dilakukan dengan wawancara dan dokumentasi; dan (2) melakukan pengolahan data tersebut kemudian mengevaluasi data tersebut.

\section{HASIL PENELITIAN DAN PEMBAHASAN}

\subsection{Hasil penelitian}

Perbendaharaan piutang PT. Angkasa Pura I (Persero) Cabang Manado. Perbendaharaan piutang pada PT. Angkasa Pura I (Persero) Cabang Manado ditangani langsung oleh bagian piutang atau account receivable. Bagian account receivable mengatur semua penjualan yang dilakukan secara kredit sesuai yang tercantum dalam peraturan yaitu ketentuan dalam lampiran keputusan direksi PT.Angkasa Pura I (Persero) Nomor KEP.77/KU.19/2015 tentang pedoman pelaksanaan kegiatan perbendaharaan piutang dan pengelolaan dana PT.Angkasa Pura I (Persero) pada bab III dijelaskan perbendaharaan piutang.

Perlakuan akuntansi atas piutang tak tertagih pada PT. Angkasa Pura I (Persero) Cabang Manado yaitu dilakukan dengan metode pencadangan atau allowance method di mana perusahaan mencatat beban piutang tak tertagih dengan mengestimasi jumlah piutang tak tertagih pada akhir periode akuntansi dan pada PT. Angkasa Pura I (Persero) dilakukan 2 kali dalam setahun yaitu setiap bulan juni dan desember. PT. Angkasa Pura I (Persero) melakukan pencadangan kerugian piutang dengan menghitung cadangan penurunan nilaipiutang. Piutang yang dihitung tersebut merupakan piutang yang telah melewati umur tertentu yang biasanya telah lebih dari 181 hari. Untuk perhitungan cadangan penurunan nilai piutang biasanya pihak perusahaan menggunakan rumus tingkat diskonto. Jadi, misalnya untuk customer X nilai piutang s/d tahun 2020 adalah senilai Rp. 1.000.000.000 dan umur piutangnya adalah 5 tahun dan besar kemungkinan piutang tersebut merupakan piutang tak tertagih. Kemudian, perusahaan melakukan cadangan penurunan nilai piutang customer sebagai berikut :

Rumus Tingkat Diskonto :

Estimasi piutang tak tertagih $\mathrm{x}$ tingkat diskonto (10\%)

Mis : Estimasi piutang tak tertagih : 20\% dari Rp.1.000.000.000,-

$$
\text { : Rp.200.000.000,- }
$$

Estimasi piutang tak tertagih $\mathrm{x}$ tingkat diskonto $(10 \%)$

Rp.200.000.000,- x 10\% = Rp. 20.000.000,-

Total piutang tak tertagih : Rp. 200.000.000,- + Rp. 20.000.000,-

$$
\text { : Rp. 220.000.000,- }
$$

Jadi, total piutang tak tertagih customer X menjadi Rp.220.000.000,-.

Piutang tak tertagih yang telah mengalami penurunan nilai piutang kemudian menjadi beban operasional perusahaan sehingga mengurangi saldo laba operasional perusahaan tetapi, jika customer melakukan pelunasan setelah dilakukan penurunan nilai piutang tersebut maka piutang tersebut diakui sebagai pendapatan oleh perusahaan.

Pengakuan piutang tersebut menjadi tidak tertagih yaitu saat bersamaan klien memberikan pernyataan bahwa tidak dapat melunasi piutang tersebut. Perusahaan kemudian melakukan penyitaan terhadap aset klien tersebut sehingga nilai kerugian piutang yang dilaporkan merupakan nilai yang telah dikurangi dengan hasil penjualan aset sitaan klien. 
Pengukuran adalah Nilai piutang yang diukur tidak hanya mencakup umur piutang tetapi juga mencakup jumlah yang diberikan yang mencakup nilai wajar, nilai piutang yang disajikan dalam laporan keuangan PT. Angkasa Pura I (Persero) Cabang Manado merupakan nilai wajar yaitu perusahaan mengestimasikan piutang tak tertagih dengan menggunakan metode pencadangan atau penyisihan.

Pencatatan yang dilakukan PT. Angkasa Pura I (Persero) menggunakan basis akrual (accrual basic). Kemudian, perusahaan mencatat piutang tak tertagih dengan metode penyisihan atau pencadangan yang biasanya dilakukan 2 kali dalam 1 tahun. Pencatatan yang dilakukan pihak perusahaan sendiri yaitu dengan mencatat jurnal sebagai berikut :

Beban Penurunan Nilai Piutang xxx

Piutang

$\mathrm{XXX}$

Penyajian pada PT. Angkasa Pura I (Persero) memiliki sistem perlakuan akuntansi dengan metode pencadangan maka dilakukan perhitungan cadangan penurunan nilai piutang apabila piutang telah melewati umur tertentu. Berikut merupakan tampilan cadangan penurunan nilai piutang pada neraca.

\section{Piutang $\quad$ xxxxxx \\ (cadangan penurunan nilai piutang) $(\mathrm{xxxxx})$}

Pengungkapan dalam akuntansi adalah sebuah proses penjelasan secara naratif atau rincian mengenai angka-angka dalam laporan neraca, laporan laba rugi, dan laporan arus kas. Pengungkapan piutang tak tertagih pada PT. Angkasa Pura I (Persero) diungkapkan pada Catatan Atas Laporan Keuangan perusahaan karena pada laporan keuangan perusahaan tidak diungkapkan secara langsung tetapi telah mengalami penurunan nilai.

\subsection{Pembahasan}

Penggolongan piutang menurut PT. Angkasa Pura I (Persero) Cabang Manado sendiri yaitu piutang yang berumur 30 hari sampai dengan 90 hari dikategorikan menjadi piutang lancar dan perusahaan mengeluarkan surat peringatan yang pertama dan apabila dalam jangka waktu 7 hari klien tidak dapat melunasi piutang tersebut maka dikeluarkan surat peringatan yang kedua. Piutang dengan umur 91 hari hingga 180 hari dikategorikan menjadi piutang kurang lancar dan dikategorikan menjadi piutang macet saat klien tidak dapat melunasi dalam jangka lebih dari 181 hari.

Pengakuan piutang tak tertagih PT. Angkasa Pura I (Persero) Cabang Manado ketika terjadi penghapusan langsung terhadap piutang macet atau piutang tak tertagih tersebut. PT. Angkasa Pura I (Persero) Cabang Manado tidak membuat penyisihan piutang tak tertagih maka beban piutang tak tertagih diakui bersamaan dengan pernyataan klien bahwa mereka benar-benar tidak bisa melunasi hutangnya. Pengakuan sebuah piutang menjadi piutang tak tertagih biasanya diakui bersamaan dengan pengakuan klien bahwa klien tersebut tidak dapat melunasi piutang tersebut.

Pengukuran sebuah piutang menjadi tidak tertagih diukur berdasarkan nilai estimasi piutang yang telah ditambahkan dengan nilai diskonto. Piutang yang berumur lebih dari 181 hari dikategorikan menjadi piutang macet atau tidak tertagih. Berdasarkan hasil penelitian jika dikaitkan dengan Standar Akuntansi Keuangan dalam PSAK No.55 (Revisi 2014), PT. Angkasa Pura I (Persero) telah menerapkan pengakuan dan pengukuran instrument keuangan dengan tepat yaitu piutang diakui pada saat terdapat bukti objektif bahwa piutang tersebut mengalami kerugian penurunan nilai atau tidak dapat dilunasi dan diukur berdasarkan nilai sekarang dari estimasi piutang tak tertagih yang ditambah dengan diskonto dan melaporkan nilai piutang dengan nilai realisasi bersih.

Pengungkapan instrumen keuangan diatur dalam PSAK 60 (Revisi 2014) dan piutang merupakan salah satu instrumen keuangan. Pengungkapan piutang tak tertagih pada 
PT. Angkasa Pura I (Persero) telah sesuaidengan PSAK 60 (Revisi 2014) yaitu pengungkapan instrumen keuangan menggunakan nilai wajar dimana pada PT. Angkasa Pura I (Persero) menggunakan nilai piutang yang sekarang yang telah dihitung berdasarkan estimasi piutang tak tertagih ditambah dengan tingkat diskonto.

\section{KESIMPULAN DAN SARAN}

\subsection{Kesimpulan}

Setelah melakukan pembahasan mengenai perlakuan akuntansi atas piutang tak tertagih pada PT. Angkasa Pura I (Persero) Cabang Manado maka diambil kesimpulan sebagai berikut : (1) perlakuan akuntansi dilakukan dengan metode pencadangan, (2) pengakuan piutang tak tertagih diakui pada saat customer mengakui bahwa tidak dapat melunasi piutangtersebut dan telah sesuai PSAK 50, (3) piutang tak tertagih diukur berdasarkan estimasi piutang tak tertagih ditambah nilai diskonto, (4) piutang tak tertagih dicatat dengan metode pencadangan, (5) piutang tak tertagih dicantumkan dalam akun cadangan penurunan nilai piutang, (6) pengungkapan piutang tak tertagih diungkapkan pada Catatan Atas Laporan Keuangan.

\subsection{Saran}

Saran yang dapat diberikan dari penelitian ini kepada PT. Angkasa Pura I (Persero) Cabang Manado yaitu untuk lebih meminimalisir piutang macet atau piutang tak tertagih perusahaan harus memberikan perhatian khusus saat akan menentukan klien yang akan aman dan kurang aman dalam melakukan pembayaran kepada pihak perusahaan untuk menekan tingkat piutang tak tertagih agar tidak terjadi di kemudian hari.

\section{DAFTAR PUSTAKA}

Ahmad, S. S. (2015). Intermediate accounting. Jakarta: AV Publisher Hery. (2015). Pengantar akuntansi comprehensive edition. Jakarta: PT. Grasindo.

Ikatan Akuntan Indonesia. (2013). Pernyataan Standar Akuntansi Keuangan No. 1 tentang Laporan Keuangan, Edisi Revisi 2013. Jakarta: PT. Raja Grafindo

Ikatan Akuntan Indonesia. (2014). Pernyataan Standar Akuntansi Keuangan No. 50 tentang Instrumen Keuangan: Penyajian, Edisi Revisi 2014. Jakarta.

Ikatan Akuntan Indonesia. (2014). Pernyataan Standar Akuntansi Keuangan No. 55 tentang Instrumen Keuangan: Pengakuan dan Pengukuran, Edisi Revisi 2014. Jakarta.

Ikatan Akuntan Indonesia. (2014). Pernyataan Standar Akuntansi Keuangan No. 60 tentang Instrumen Keuangan: Pengungkapan, Edisi Revisi 2014. Jakarta.

Kasmir. (2015). Bank dan lembaga keuangan lainnya. Jakarta: PT. Raja Grafindo Persada.

Kartikahadi, H., Sinaga, R. U., Syamsul, M., Siregar, S. V., \& Wahyuni, E. T. (2016). Akuntansi keuangan berdasarkan SAK berbasis IFRS Buku 1. Jakarta: Salemba Empat.

Kieso, D. E., Weygandt, J. J., \&Warfield, T. D. (2008). Akuntansi intermediate. Jakarta: Erlangga.

Lubis, A. I. (2011).Akuntansi keperilakuan. Edisi 2. Jakarta: SalembaEmpat.

Martani, D., SiregarV. S., Wardhani, R., Farahmita, A., \& Tanujaya, E. (2015). Akuntansi keuangan menengah berbasis PSAK. Jakarta: Salemba Empat.

Pura, R. (2012). Pengantar akuntansi I: Pendekatan siklus akuntansi. Jakarta: Penerbit Erlangga.

Suwardjono. (2015). Teori akuntansi: perekayasaan laporan keuangan.Yogyakarta: BPFE Yogyakarta.

Sugiyono. (2015). Metode penelitian bisnis. Cetakan ke-15. Bandung: Alfabeta.

Sujarweni, W.V. (2014). Metodologi penelitian.Yogyakarta: Penerbit Pustaka Baru Press. 